\title{
Denying the Animosity: Understanding Narratives of Harmony from the Nellie Massacre, 1983
}

Jabeen Yasmeen

Indian Institute of Technology

Follow this and additional works at: https://digitalcommons.usf.edu/gsp

\section{Recommended Citation}

Yasmeen, Jabeen (2020) "Denying the Animosity: Understanding Narratives of Harmony from the Nellie Massacre, 1983," Genocide Studies and Prevention: An International Journal: Vol. 14: Iss. 2: 2-19.

DOI:

https://doi.org/10.5038/1911-9933.14.2.1732

Available at: https://digitalcommons.usf.edu/gsp/vol14/iss2/4

This Articles is brought to you for free and open access by the Open Access Journals at Digital Commons @ University of South Florida. It has been accepted for inclusion in Genocide Studies and Prevention: An International Journal by an authorized editor of Digital Commons @ University of South Florida. For more information, please contact digitalcommons@usf.edu. 


\section{Denying the Animosity: Understanding Narratives of Harmony from the Nellie Massacre, 1983}

\section{Acknowledgements}

I would like to thank my PhD supervisor Dr. Paulomi Chakraborty for her feedback on the article and the Indian Institute of Technology Bombay for funding my attendance in the conference "Denial: The Final Stage of Genocide" at University of North Carolina at Charlotte, where parts of this paper were first selected and presented. 


\title{
Denying the Animosity: Understanding Narratives of Harmony from the Nellie Massacre, 1983
}

\author{
Jabeen Yasmeen \\ Indian Institute of Technology \\ Bombay, Maharashtra, India
}

\section{Introduction}

In early 2019, India geared up for another general election that would decide if the ruling Bharatiya Janata Party (BJP) government led by Prime Minister Narendra Modi would return to power. ${ }^{1}$ On the one hand, supporters of Modi vouched for his charisma and the realization of developments promised in the campaigns during the last general election in 2014; but on the other, critics predicted that the threat to the constitutional pillar of secularism may be reinforced with renewed vigor if the BJP returned to power. ${ }^{2}$ This fear was based on varied developments in the country from 2014-2019. One of them was the fear of the disenfranchisement of about four million people in the state of Assam. The release of the National Register for Citizens (NRC) in Assam had almost four million names missing from its final draft, which threatened to create the largest potential cluster of stateless people, a majority of them being Muslims of East Bengal origin. ${ }^{3}$ In addition, the Citizenship Amendment Bill of 2016 proposed that citizenship be given to refugees belonging to six persecuted communities from Afghanistan, Pakistan, and Bangladesh, which excluded Muslims. These both signal the dangerous shifting of India toward the idea of a pro-Hindu right-wing nation. ${ }^{4}$ The Citizenship Amendment Bill of 2016 was passed into an Act on December 2019, which led to widespread protests throughout, as well as beyond India, ${ }^{5}$ these protests were ongoing during the writing of this paper in 2019/2020. Observers equate the Act's exclusion of Muslims, along with the provisions of the NRC as an early stage of genocide. ${ }^{6}$ It resonates with Gregory H. Stanton's identification of the early stages of genocide, which may not be linear. ${ }^{7}$ The atmosphere of fear generated during the first term of the BJP government became more tangible during its second term. As the country shifts towards non-secularism, it is useful to understand how the fracture has occurred in a nation that has always seemingly been at peace with its multiethnicity and multireligiosity. Was this peace merely on the surface?

Gyanendra Pandey contends in Remembering Partition that in narratives that assert harmony, "the slippages occur in the very accounts that signal such a mutual constitution and that the communities are necessarily fragile and open to question." 8 This article tries to understand this idea of "mutual constitution"9 and fragility through oral narratives from certain periods in recent Indian history. Doing so makes it possible to reflect on how societies in India adhere to a narrative of harmony that had existed between different communities before a conflict breaks out, which denies the existence of any palpable enmity or differences among the communities. This article

${ }^{1}$ Joanna Slater and Nisah Masih, “India's 2019 Elections: What You Need to Know," The Washington Post, May 22, 2019, accessed January 30, 2020, https://www.washingtonpost.com/world/2019/03/11/indias-elections-what-you-needknow/.

${ }^{2}$ Ibid.

${ }^{3}$ Agence France-Presse (AFP), "Assam NRC: Over Four Million People Left Off-Draft Since Enforcement of Exercise, Muslims Majority Among Those Who 'Fear for Future,"' Firstpost, July 14, 2019, accessed July 15, 2019, https://www. firstpost.com/india/assam-nrc-over-four-million-people-left-off-draft-since-enforcement-of-exercise-muslims-majorityamong-those-who-fear-for-future-6989831.html.

${ }^{4}$ The Citizenship (Amendment) Bill of 2016 (Bill No. 172 of 2016, July 15, 2016), (Rep. of India), accessed January 20, 2020, https://www.prsindia.org/sites/default/files/bill files/Citizenship (A) bill, 2016 0.pdf.

${ }^{5}$ The Citizenship (Amendment) Act of 2019 (Act No. 47 of 2019, December 12, 2019), (Rep. of India), accessed December 16, 2020, http://egazette.nic.in/WriteReadData/2019/214646.pdf.

${ }^{6}$ G. Sampath, "Are Fears over the Citizenship (Amendment) Act Misplaced?" The Hindu, December 19, 2019, accessed December 20, 2019, https://www.thehindu.com/opinion/op-ed/are-fears-over-the-citizenship-amendment-actmisplaced/article30341818.ece.

${ }^{7}$ Gregory H. Stanton, “The Ten Stages of Genocide," Genocide Watch, accessed August 1, 2020, https://www.genocidewatch. com/ten-stages-of-genocide.

${ }^{8}$ Gyanendra Pandey, Remembering Partition: Violence, Nationalism and History in India (Contemporary South Asia), (Cambridge: Cambridge University Press, 2001), 188.

${ }^{9}$ Ibid.

Jabeen Yasmeen. "Denying the Animosity: Understanding Narratives of Harmony from the Nellie Massacre, 1983." Genocide Studies and Prevention 14, 2 (2020): 2-19. @2020 Genocide Studies and Prevention.

https://doi.org/10.5038/1911-9933.14.2.1732 
further seeks to analyze the "slippages" and see where and how societies are "open to question" chiefly in the context of the Nellie Massacre of $1983 .{ }^{10} \mathrm{I}$ also refer to two recent forms of violence in contemporary India, while drawing from the Partition of India in $1947 .{ }^{11} \mathrm{I}$ analyze oral narratives from Nellie to understand how and why the narrators from a conflict-affected society unfailingly emphasize a familial structure to refer to their relationship with members of other communities such as "brothers," "sisters," "father-like," or "mother-like." In this paper, I argue that, their emphasis on a familial structure hints at the fact that nations and ethnic communities imagine themselves as a family despite underlying problems. Does this choosing to remember only the harmony of the past contribute to a (genocide) denial? If it is indeed denial, does it fuel the conditions for further genocide in the present, or is it an attempt to mend existing fault lines to achieve a saner society? Is there any difference between a Hindu, belonging to the majority (Sikhs, in the case of Partition), asserting peaceful co-existence and a Muslim, belonging to the minority, doing the same? I argue that there is. While both may stand in a position of geographical constraint due to the sharing of neighborhoods and may emerge from values of secularism inculcated in them from being part of a multiethnic society, members of the minority community may also be affected by fear of retaliation from the majority. This paper is divided into three sections. The first section introduces the Nellie Massacre of 1983. It considers oral narratives from Nellie, almost thirty-three years after the event took place. This section underscores how many of the testimonies tend to hold on to a narrative of harmony, but few refer to the problems that had existed before the conflict. The second section goes back in time to narratives from the Partition in 1947 and tries to understand how the concepts of "family" and "brotherhood" is recurrent in these narratives. This section makes it clearer that a sense of perpetual denial exists in consigning the violence to a suddenness and in not accepting that it erupted from within the society. The third section returns to the present to analyze the concept of secularism prevalent in post-Independence India and how this ideal influences the narratives of harmony along with the reality that communities in mixed societies, such as in India, have to coexist with one another. This section also leads to the perpetual challenge of Muslim minorities being seen as the foreigner, which affects narratives in post-conflict societies. These three sections together imply that although conflict-afflicted societies try to project the picture of a harmonious family, there are faultlines that exist and require acknowledgment to heal.

\section{Method}

This paper chiefly draws upon oral narratives from Nellie as a primary source. They were collected using a non-probability snowball-sampling methodology over the period of a year, primarily between March 2016 and September 2016. The names of the respondents from Nellie I use throughout the paper are fictional. While I stick to a logic of naming the respondents according to their community and gender affiliations, I choose to use fictitious names so as not to endanger the respondents who still live in a sensitive society through the use of their real names. This society still hangs on a delicate balance of harmony, years after the massacre discussed in this paper. In trying to choose, link, and analyze the narratives, I employ the idea of secularism, as embedded in post-Independence Nehruvian ideals, to which scholars such as Needham and Sunder Rajan refer. ${ }^{12}$ Despite attempts to promote these ideals of secularism in a mixed society such as in India, fractures in society have led to what Gregory Stanton identifies as the early stages of genocide: classification, symbolization, discrimination, and organization. ${ }^{13}$ In trying to understand the oral narratives from Nellie, I also refer to the scholarship of Gyanendra Pandey, Urvashi Butalia, Dipesh Chakrabarty, Paul R. Brass, Raheel Dhattiwala and others. ${ }^{14}$ Lastly, in my discussion of recent

\footnotetext{
${ }^{10}$ Ibid.; the Nellie Massacre may also be referred to as "Nellie" throughout the article.

${ }^{11}$ Pandey, Remembering Partition, 188.

${ }^{12}$ Rajeswari Sunder Rajan and Anuradha Dingwaney Needham, "Introduction," in The Crisis of Secularism in India, ed. Anuradha Dingwaney Needham and Rajeswari Sunder Rajan (Ranikhet: Permanent Black, 2009), 1-42.

${ }^{13}$ Stanton, The Ten Stages of Genocide.

${ }^{14}$ Pandey, Remembering Partition, 188; Urvashi Butalia, The Other Side of Silence: Voices from the Partition of India (New Delhi: Penguin Books, 1998); Paul R. Brass, "The Partition of India and Retributive Genocide in the Punjab, 1946-47: Means, Methods and Purposes," Journal of Genocide Research 5, no. 1 (2003), 72, accessed December 20, 2019, doi: https://
} 
incidents of violence, I draw on secondary sources and, particularly reports from newspapers, many of which are digital publications. The oral narratives collected from my field research will be interspersed throughout the paper.

\section{The 1983 Nellie Massacre and All is Well}

Nellie is a cluster of approximately sixteen villages in Morigaon in Assam. On February 18, 1983, Hindu Assamese and indigenous tribal neighbors attacked Nellie killing almost 2,000 people in just a span of a few hours. The attacked residents primarily belonged to the Bengali-speaking Muslim community whose predecessors had migrated from former East Bengal, now Bangladesh, from as early as the 1930s. The attack happened at the peak of the Assam Agitation, a movement that had sought to oust infiltrators from neighboring Bangladesh..$^{15}$ Those attacked were perceived as foreigners. As one of the worst mass-killings in post-Independence India, the Nellie massacre has not gained much representation in mainstream discourse, or academic, and journalistic or popular writings despite its scale and political significance. It is debatable whether the Nellie massacre should be referred to as a massacre and not a genocide. I have observed that although it is referred to as a massacre it should rather be named a genocide due to the assailants' intent to wipe out a certain community.

It was the death of a Parliamentary representative, Hiralal Patowary, in 1979 that became the immediate context of the Assam Agitation or Assam Movement. During the re-election process that followed his death, the number of voters increased significantly. The All Assam Students' Union (AASU) assumed that that this surge was due to the enlistment of illegal foreigners and demanded that the elections be rescheduled, and the list be revised. ${ }^{16}$ Nevertheless, assembly elections were declared-almost 45,000 enrolled voters were proved to be foreigners. AASU demanded that voters' lists for other constituencies also be released. ${ }^{17}$ Despite prevailing tensions and warnings from senior police officials, elections were held on February 14 and 17, 1983. The leaders of the Assam Movement called people to boycott the elections. While most of Assamese society abstained from voting, a section of the Bengali-speaking Muslim minority voted, which enraged the Assam Movement leaders. ${ }^{18}$ The participation in the elections by a section of the Bengali-speaking Muslim minority is believed to have led to the massacre. Scholars, such as Makiko Kimura, Sanjoy Hazarika, Monirul Hussain, also cite that the local Lalung (Tiwa) tribe and other scheduled caste ${ }^{19}$ Hindus in and around Nellie were provoked to believe that the land abandoned by the Bengali-speaking Muslims would become theirs after the massacre. ${ }^{20}$ Most of the land in Nellie and its neighboring areas had belonged to the Tiwas traditionally but was sold off to the Muslims of East Bengal, who had started migrating into Assam from as early as the 1930s. ${ }^{21}$ Makiko Kimura argues in her book, The Nellie Massacre of 1983: Agency of Rioters, (the lone academic monograph on the Nellie massacre), that the attackers, which constituted the Tiwas, the Karbis, and the Hindus in the area, had attacked in self-defense ${ }^{22}$-it was a particularly troubled time in Assam and rumors were rife that the Bengali-speaking Muslims were planning to attack the Tiwa village and the Assamese Hindu villages in the area. ${ }^{23}$ The locals, both survivors as well as perpetrators, do not assign a historicity

doi.org/10.1080/14623520305657.; Dipesh Chakrabarty, “Remembered Villages: Representations of Hindu-Bengali Memories in the Aftermath of the Partition," Economic and Political Weekly 31, no. 32 (1996), 2143, accessed October 4, 2018, https://www.jstor.org/stable/4404497; Raheel Dhattiwala, Keeping the Peace: Spatial Differences in Hindu-Muslim Violence in Gujarat in 2002 (New York: Cambridge University Press, 2019).

${ }^{15}$ Makiko Kimura, The Nellie Massacre of 1983: Agency of Rioters (New Delhi: Sage Publications, 2013), 1.

${ }^{16}$ Diganta Sharma, Nellie, 1983 (Jorhat: Ekalabya Prakashan, 2007), 6.

${ }^{17}$ Ibid.

${ }^{18}$ Ibid., 7.

19 "Scheduled caste" refers to constitutionally recognized groups of people who are considered as lower caste according to Hindu scriptures and practices.

${ }^{20}$ Kimura, The Nellie Massacre of 1983, 101.

${ }^{21}$ Ibid., 96.

${ }^{22}$ Ibid., 106.

${ }^{23}$ Ibid., 107. 
to the massacre-they see it as an isolated incident. For them, the cause was more immediate-the elections and self-defense, respectively.

A tone of fond remembrance can be detected when Abdul Kazi, a Bengali-speaking Muslim villager from Muladhari in the Nellie area, recalls in an interview with me, how a villager from the Hindu neighborhood offered to escort him back to his village on a dark night. ${ }^{24}$ This event was before the massacre. Kazi remembers how he was often addressed as Bhai or brother on those days and how his Hindu neighbors worried the roads might not be safe for him to travel at night. They would give him a torch to help him walk back in the darkness. ${ }^{25}$

Another Muslim respondent, Riyazuddin, in his late fifties recalled his childhood. As children, they did not have any sense of being religiously different. He would visit his friend's house and be served food by his friend's mother in their kitchen. Even now, thirty years after the massacre, there would be exchanges of curries with his Hindu neighbors. ${ }^{26}$ Despite such bonhomie in the past and present, the respondent is forced to question the nature of the harmony that had allowed for such a massacre to happen. The reception of a community, seen as the alien, into the domestic space (in stark contrast to the society before the Partition, as I discuss later), does not seem to guarantee the acceptance of their political identity. Nor does it, as a result, guarantee their acceptance into the social and political space. The simultaneous coexistence of bonhomie and acrimony in a society can be seen as resembling contradictory behavior. Bradley Campbell points out how an individual can be both the savior and the perpetrator during a genocide. ${ }^{27}$ The pre-massacre society of Nellie seems to reflect this contradictory behavior of being the friendly neighbor as well as the attacker.

While Abdul Kazi and Riyazuddin are members of the survivor community, narratives of the community of the accused also reference this sentiment of bonhomie. Lovingly called "father" by all, Mahen Das is a venerated figure for both Hindus and Muslims in the area. While discussing the long history of migration and settlement of the migrant Bengali speaking Muslim community in the interior villages of Nellie, he clarifies, "one cannot say Hindu and Muslims to be different here." ${ }^{28} \mathrm{He}$ delights in the fact that everyone, irrespective of religion, comes and pays obeisance to him as a community elder as they also accept that he was indicted as one of the major accused in the cases that were filed in court. The respondents in the survivors' villages refer to how this old man was tied to a pillar in his house when he had tried to protest the massacre, but the old man never brings it up even in a two-hour long discussion. The survivors prefer to believe that the venerated fatherly figure had tried to protect them, while the same father figure remains seemingly oblivious to this myth-making.

A Tiwa man, Ramesh Pator, from the neighborhood reports,

[t]he brotherhood among people is very strong here. There was an all-India Muslim istema [religious congregation] organized here. We also co-operated in there. [...] People from Upper Assam ${ }^{29}$ had come. They were expecting the Hindus here to be hostile. They later told that, when they had to walk such a long distance, had difficulties eating and drinking, all were resolved. The little differences remaining in the society was dissolved due to the istema. It was held in 2013. ${ }^{30}$

As Pator tries to ascertain whether all is well, it slips into his narrative that all might not have been well: the differences are solved gradually. Despite such deliberate slippages, he prefers to call the bond a brotherhood, while hinting emphatically at the harmony that had consolidated only decades after the massacre. ${ }^{31}$ This claim to brotherhood is contested in the account of the father of

\footnotetext{
${ }^{24}$ Abdul Kazi, interview with author, September 16, 2016.

${ }^{25}$ Ibid.

${ }^{26}$ Riyazuddin, interview with author, March 10, 2016.

${ }^{27}$ Bradley Campbell, "Contradictory Behaviour During Genocides," Sociological Forum 25, no. 2 (2010), 296-314, accessed December 22, 2019, https://www.jstor.org/stable/pdf/40783395.pdf.

${ }^{28}$ Mahen Das, interview with author, September 23, 2016.

31 "Brotherhood" is a very gendered term in these narratives. It speaks of a society where male-to-male inter-community interactions are more prevalent. Bonding amongst women of the two communities in Nellie was not referenced
} 
a person who had dropped out of school due to bullying from the children of other communities. This event was during another phase of violence which happened in the state in the early 2000s against the Bengali-speaking Muslim community. He says,

[d]uring that time, these children could not study in peace. They were threatened that they will be cut into pieces. "Do not come to school." The teachers were given complaints. He would come to me and say, "Father, how do we go to school?" They would pull his hair, pull his clothes from behind, pinch him. They would hit from behind if he sits in the front, take away his pen or copy. He would come and tell us; we would ask him to go to the teacher since we know no one else. Even if the teacher would scold them, it continued. So, my son stopped going to school..$^{32}$

This account seems to reiterate an oft-heard statement of children who have been bullied at school: "children are cruel." Such cruelty may be what children bring and emulate from their elders, their family, and society in general. Bullying may be a situation where the filtered narratives of harmony slipped to reveal how the children are conditioned to perceive and treat someone from a different community. The violence underlying this bullying is a replay of the violence of the Nellie massacre. Both communities must have passed down the memory of the massacre to younger generations. Such threats of violence, likely bullying, indicate how society continues to recover years after the conclusion of violence.

Friction in the pre-conflict society is referred to again when a local tribal (Tiwa) leader remembers the social conditions right before the massacre.

These people [Bengali-speaking Muslims] started creating nuisance in our villages around. Nobody would have cows in their shed, they would be stolen. They would steal in people's houses too, putting the people in trouble. We had our fields where the people were settled. When the paddy would be ripe for harvest, they would reap them off at night. There were some troubles and then Assam Agitation also came in. As far as I know, our people were not very willing to participate in it but, there were instigations of Assam Agitation as well as some influence of the RSS. So, the incident of February 18, 1983 happened. ${ }^{33}$

This local leader's version comes dangerously close to denial by blaming the victim community for what happened. He makes it certain that he does not intend to incriminate the Assamese Muslims with whom he shares a very cordial relationship when he refers to them as those "whom we even address as uncles, my father's friends and all." ${ }^{34}$ As one of the leaders of the communities, he seems to be well aware of the fact that his version has to be balanced. He does not want to negate the differences that existed in the pre-conflict society, but he is careful not to implicate his own community.

Most of the narratives from Nellie prefer to remember a society in which the neighboring communities coexisted peacefully. Even though they try to conform to the practice of brotherhood and harmony, their narratives complicate the picture of idealistic coexistence. In doing so, sometimes one becomes close to denial by blaming the victims for the problems that led to the attack. When the narrators of both the communities accept that there were, and still are, problems existing within the communities, they tend to indicate an awareness of the possible reasons of animosity and a willingness to prevent it in the future. When they prefer to characterize a society as like a family-brothers, uncles, and fathers-they repeat what is common in many post-genocide survivor narratives: they deny the root cause of the conflict, hence denying the event itself.

This pattern of denial of the problem through re-enacting familial bonds with members of the other community as "uncles," "father," and "brothers" is an attempt to rearrange the society in a

during the interviews.

${ }^{32}$ Muslim Man 2, interview with author, September 16, 2016.

${ }^{33}$ Tribal Leader, interview with author, September 24, 2016.

${ }^{34}$ Ibid. 
familial structure while also trying to normalize any conflict because families do have everyday minor conflicts. The "rhetoric of family" serves as a "discursory anchor for a host of non-familial references," observes Leslie J. Miller. ${ }^{35}$ According to Miller, the "ideal of the harmonious domestic or 'bourgeois' family is among the sturdiest set pieces in the modern cultural repertoire," and we are "overwhelmingly committed to upholding a unified and harmonious image of family life." ${ }^{36}$ The idea of a family, thereby, is an image to be "upheld" to the outer eye. What goes on inside may be different from what meets the eye, but the surface has to appear harmonious. The recurring pattern of being a family in a community afflicted by violence therefore may be a façade and thus a denial.

\section{The Partition, 1947, "Brotherhood," and Denial}

The denial of violence within and the consignment of violence to the outside is a recurrent pattern in Partition narratives, as Gyanendra Pandey observes. ${ }^{37}$ This denial occurs with standard stories of exceptional peace and harmony. Such denial is repeated in most of the narratives where the societies fail to address what Pandey remarks as "disorders that is somehow a part of our history too." ${ }^{\prime 38}$ In 1947, British India was divided into India, and East and West Pakistan. ${ }^{39}$ Along with a mass exodus, this division, known as the Partition, also led to an episode of unprecedented violence and bloodshed when the communities-Hindus, Sikhs, and Muslims-killed, maimed, and raped individuals of the other communities. ${ }^{40}$ Paul R. Brass considers the Partition a retributive genocide. ${ }^{41}$ The "genocidal massacres" during the Partition were not ordered by the state nor were they unorganized and spontaneous ${ }^{42}$ The violence between the communities was mutual. ${ }^{43}$ If one considers the Partition a genocide, even though the violence lacked "genocidal intent," hearing survivors mostly choosing to remember a society that was harmonious right before the Partition becomes increasingly intriguing. ${ }^{44}$

Urvashi Butalia's book, The Other Side of Silence, recounts many such narratives where the survivors, regardless of their community, remember the "brotherhood" that existed right before the violence of Partition took over. Butalia cites an interview from Satti Khanna and Peter Chappell's film on the Partition, A Division of Hearts (1987). ${ }^{45}$ Murad was a child in Lahore when the Partition happened. He recounts,

[i]n the past Hindus and Muslims lived like brothers, and looked after each other. Even a big landlord would offer all kinds of help when a poor menial worker was getting married. [...] There was a lot of fellow feeling. But when Partition took place, everything got turned upside down. They pierced even infants with their spears $[\ldots]$ they started hating each other. There was such harmony before this. ${ }^{46}$

Murad's narrative continues to emphasize that there was a strong camaraderie and brotherhood amongst the communities before the Partition violence. Despite referring to the monstrosity of infants being "pierced", Murad's narrative returns to underscore that "there was such harmony before this." ${ }^{\prime 7}$ Along with the violence of the Partition, Murad also chooses to remember a society

\footnotetext{
${ }^{35}$ Leslie J. Miller, “Violent Families and the Rhetoric of Harmony," The British Journal of Sociology 41, no. 2 (1990), 265, accessed May 6, 2019, https://www.jstor.org/stable/590873.

${ }^{36}$ Ibid., 263-264.

${ }^{37}$ Pandey, Remembering Partition, 188.

${ }^{38}$ Ibid., 174.

${ }^{39}$ Gyanendra Pandey, Routine Violence: Nations, Fragments, Histories (California: Stanford University Press, 2006), 133

${ }^{40}$ Brass, The Partition of India, 76.

${ }^{41}$ Ibid., 72.

${ }^{42}$ Ibid.

${ }^{43}$ Ibid.

${ }^{44}$ Ibid.

${ }^{45}$ Satti Khanna and Peter Chappell, dirs., A Division of Hearts (New York: Icarus Films, 1987), 57 minutes.

${ }^{46}$ Butalia, The Other Side of Silence, 294.

${ }^{47}$ Ibid.
} 
where there was no conflict, thus choosing to overlook that there might have been already existing tensions brewing in pre-Independence India that led the way to the Partition. Even if one discounts Murad's narrative as the recollections of an adult who was a child then, there are other narratives which came from an adult during the Partition, such as Basant Kaur. Although she speaks of the violence inflicted during the Partition, she also remembers how different communities had lived in close geographical proximity and attended functions with each other's families-"in our village there were a few Musalmaan [Muslim] families, but we never had any problem. We lived together, there were marriages, we would attend them, we lived fairly close to each other. Close by there were other villages where you would find Musalmaans, Tihai, Saintha, Sadiok, Sadda, small villages." ${ }^{48}$

Bir Bahadur Singh, Basant Kaur's son, also references social proximity in his account, but his narrative gradually addresses what Kaur had preferred to gloss over - the underlying discrimination in the narratives of harmony. Singh starts with how the Muslims, Hindus, and Sikhs were a close community with frequent social and economic exchanges. Despite this relationship, there were instances when the Hindus treated the Muslims differently. This was most evident in the exchange of food between the Hindus and Sikhs and the Muslims. The Muslims would have to offer uncooked food to the Hindus and Sikhs when the latter would visit them during any function or otherwise, because the Hindus and Sikhs would not eat food cooked in a Muslim house or with a utensil used by a Muslim. Singh remembers, "you see we used to drink milk from their houses, but the milk had to be in an unused utensil, a new one." ${ }^{\prime 49}$ He further elaborates that if the Muslims were served food in a Hindu or Sikh house, the bread would be thrown to their plates, so the server does not become polluted. Such differential treatment can be equated with untouchability and caste-violence, as posited by Kalpana Kannabiran. ${ }^{50}$ Singh's account is filled with similar instances of such treatment meted out to the Muslims, which he believes was the reason for Partition. His narrative fractures the notion of brotherhood and camaraderie as superfluous and opportunistic: "they would call our mothers and sisters didi [sisters], they would refer to us as brothers, sisters, fathers, and when we needed them they were always there to help, yet when they came to our houses, we treated them so badly." ${ }^{51}$ An interviewee in Ritu Menon and Kamala Bhasin's work Borders and Boundaries says, "we neither broke bread with them, nor inter-married, but the rest was fine." ${ }^{2}$ Although the Hindu woman must have intended to underline "the rest" where everything was fine, her narrative ends up highlighting the differences and hierarchies-the communities did not have relations that were cordial enough to inter-dine or inter-marry. They were not equal or similar enough. Menon and Bhasin remark that forgetting "deep seated prejudices and taboos" and "deep affection and amity" existed alongside each other is easy. ${ }^{53}$ Such narratives of a prePartition society try to adhere to the idea that all was well in the society. The killings and rapes were seen and projected as a sudden rupture in their peaceful everyday life. Such narratives tend to overlook that fault-lines can be mended only if they are recognized. A genocidal event such as the Partition could not have taken place, if all had lived harmoniously side by side. Although the Partition had left a deep sense of resentment, it simultaneously evoked a "considerable sense of nostalgia." ${ }^{54}$ Pandey observes that it is often referred to as the "partition of siblings." ${ }^{55}$ Clinging to such nostalgia, communities choose to overlook the bitter fact that the Partition was meant to be a solution to "the 'Muslim' answer to 'Hindu Oppression' and 'Hindu Capitalism."'56

The repeated evocation of brotherhood (or similar familial relations) is a convenient

\footnotetext{
${ }^{48}$ Ibid., 203.

${ }^{49}$ Ibid.

${ }^{50}$ Kalpana Kannabiran, “Introduction: The Habitations of Violence in India," in Violence Studies, ed. Kalpana Kannabiran (New Delhi: Oxford University Press, 2016), 18.

${ }^{51}$ Ibid., 222.

${ }^{52}$ Ritu Menon and Kamala Bhasin, Borders and Boundaries: Women in India's Partition (New Brunswick: Rutgers University Press, 1998), 12.

${ }^{53}$ Ibid.

${ }^{54}$ Pandey, Remembering Partition, 2.

${ }^{55}$ Ibid.

${ }^{56}$ Ibid., 27.
} 
euphemism to express one's obliviousness to the reality of the situation. Certain narratives of the 1971 Bangladeshi war also resorted to such a tool. Yasmin Saikia interviewed Pakistani army men who had been involved in the war, for her book Women, War and the Making of Bangladesh: Remembering 1971. She found that the rhetoric of the Bangladeshis as brothers occupied the same space as them being "betrayers." ${ }^{57}$ Saikia often encountered an explanation as to why the war had happened-"the Indians had infiltrated and manipulated the Bengalis." ${ }^{58}$ The revolt of the Bengali officers in the East Bengal Regiment in March 1971 still perplexes the Pakistani Military academythey still refer to the revolt as "Brothers killing Brothers." ${ }^{59}$ Pakistan was territorially divided into East and West Pakistan. Punjabis dominated the west while Bengalis constituted the majority in the east. The Punjabi factor slowly established its prominence in Pakistan's identity and politics with the support of the Urdu-speaking immigrants from Bihar and Uttar Pradesh. The state increasingly began to favor the Urdu-speaking groups in West Pakistan with inequitable distribution of wealth between the East and West, economic exploitation, restrictions on Bengali speech in public sphere, and lack of political representation in the country's national parliament. ${ }^{60}$ These political and social realities were sidelined when the Pakistani army men still tried to grasp why and how the war had happened. Reference to their brotherhood and explaining the war as a result of India's interference seems to obliterate the "physical, emotional, political and cultural" divisions that had seeped into the two divisions of Pakistan. ${ }^{61}$

Similar denial of violence in pre-genocide societies by post-genocide narratives such as in Nellie and after the Partition may be illustrated with Dipesh Chakrabarty's explanation of the tussle between nostalgia, trauma, and history. Chakrabarty explains in the context of survivors of Partition in the east, viz. Bengal, that "a traumatized memory has a narrative structure which works on a principle opposite to that of any historic narrative," and the memory has to "place the [e]vent within a shared mythic construction of the past that gives force to the claim of the victim." ${ }^{62}$ Chakrabarty refers to a collection of essays called Chere Asha Gram (The Abandoned Village). The essays were written with a sense of tragedy where the Partition is "an inexplicable event" for the survivors..$^{63}$ They express a sense of "stunned disbelief" at the Partition. ${ }^{64}$ A running theme in this book reads, "how inexplicable it all was-neighbours turned against neighbours after years of living together in bonds of intimacy and affection, friends took up arms against friends. How did this come to pass?" ${ }^{65}$ Chakrabarty argues that the difference between history and memory is that "history seeks to explain the event, the memory of pain refuses the historical explanation and sees the event causing the pain as a monstrously irrational aberration." ${ }^{\prime 66}$ Genocides and events of conflict in mixed societies thus become "irrational aberration" that cannot be explained by history. ${ }^{67}$ The members of the majority community may want to believe that the aberration was unaccountable, notwithstanding the overt or subvert subjugation that they might have subjected the minorities to. Chakrabarty points out how secular meant the members of the minority community had to adapt the ways of the majority, not the other way around. Such subtle coercions in a mixed society indicate how the idea of secular can become narrow and less accommodating.

\footnotetext{
${ }^{57}$ Yasmin Saikia, Women, War and the Making of Bangladesh: Remembering 1971 (New Delhi: Women Unlimited, 2011$), 265$.

${ }^{58}$ Ibid., 272.

${ }^{59}$ Ibid., 72.

${ }^{60}$ Ibid., 46.

${ }^{61}$ Ibid.

${ }^{62}$ Chakrabarty, Remembered Villages, 2143.

${ }^{63}$ Ibid.

${ }^{64}$ Ibid.

${ }^{65}$ Ibid., 2144.

${ }^{66}$ Ibid.

${ }^{67}$ Ibid.
} 
Secularism, Coexistence, and the "Foreigner"

In post-Independence India, the idea of secularism can be attributed to Jawaharlal Nehru. ${ }^{68}$ Syed Mufti observed that "the ideal of the new Indian nation for Nehru was based on a non-identitarian 'Indian-ness' which would bear (only) the marks of modern citizenship." 69 Such secularism was difficult to implement in a country where even the ideologies of the leaders of the "official nationalism" before independence was predominantly Hindu, such that "the terms of national self-identifications tended to privilege Hindu identifications over those of other communities." 70

Hindu-Muslim conflicts were not uncommon in pre-Independence India. One of the first Hindu-Muslim conflict recorded was in 1859, when Hindus had taken out processions which passed mosques during the time of prayer. Ganapati (Ganesh of the Hindu pantheon) festivals had become a medium to realign the idea of an Indian with that of a Hindu. ${ }^{71}$ It was the beginning of the formulation and absorption of the extreme Hinduism ideals. The census taken by the British administration further strengthened the "self-awareness of numerical strength and territorial reach objectifying Hindu-Muslim consciousness." ${ }^{72}$ When the Hindu political parties in the 1980s rose into power, a notable section of the majority in post-Independence India had begun to believe in this "homogenous Hindu identity and culture as coterminous with the nation, India."73 They all clamored to achieve Gandhi's vision of a Ramrajya, an ideal state under Lord Ram, the incarnation of Lord Vishnu, the Hindu god, ignited by a national imagination where "Muslims and Christians remain foreigners and outsiders until such time as they give up their religious difference." ${ }^{74}$ India had become a nation where the majority Hindu perceived minority rights as an "appeasement" of the minority rather than as an attempt to ensure protection of all religions in "a hugely heterogenous nation." 75 The political mobilization of the Hindus in the name of achieving Ramrajya was cunningly, as well as ironically, rooted in the idea of the equalitarian Ramrajya envisioned by Gandhi. Gandhi's usage of the term to propagate the dream of a secular, peaceful, and efficient nation has been appropriated by the hate politics of post-Independence India to arrive on December 6, 1992 at the demolition of Babri Masjid (Mosque), which allegedly stood in the place of a Ram temple and also led to the flaring up of the communal riots soon after in several parts of the country. Observing such recurring violence in post-independence India, I would posit that implementation of secularism in India is almost an unattainable utopia-complicated and asserted further by recurrent incidents of communal violence. It is within such parameters of secularism that narrators recounting incidents of communal violence, such as the Nellie massacre, can be understood. It is the ideal of coexistence that a mixed society is expected to follow, which makes the narrators fall back on the narratives of harmony, relegating the fault-lines behind it.

Raheel Dhattiwala explains how neighboring practices in mixed societies affect occurrences and narratives of violence. In her book, Keeping the Peace, aptly subtitled Spatial Differences in HinduMuslim Violence in Gujarat in 2002, Dhattiwala refers to the Hindu-Muslim equation in Ahmedabad, a city in Gujarat. In contemporary India, Gujarat witnessed one of the worst incidents of violence (or rather, pogrom), namely the Godhra riots. ${ }^{76}$ Dhattiwala investigates two neighborhoods in Ahmedabad in Gujarat. One, Ram Rahim Nagar, remained unaffected by the riots in the city in 2002, and the other, Santoshnagar, adjacent to Ram Rahim Nagar, witnessed casualties. Dhattiwala finds that there might be "ethnic resentment" between the two communities, but in Ram Rahim Nagar harmony prevailed due to the local leadership. Violence was put in check through "informal

\footnotetext{
${ }^{68}$ Sunder Rajan and Needham, Introduction, 1-42.

${ }^{69}$ Ibid., 7.

${ }^{70}$ Ibid.

${ }^{71}$ Shabnum Tejani, Indian Secularism: A Social and Intellectual History 1890-1950 (Ranikhet: Permanent Black, 2007$), 55$.

${ }^{72}$ Dhattiwala, Keeping the Peace, 11.

${ }^{73}$ Tejani, Indian Secularism, 88.

${ }^{74}$ Ibid.

${ }^{75}$ Ibid., 20.

${ }^{76}$ Dhattiwala, Keeping the Peace, 3; Pandey, Remembering Partition, 187.
} 
monitoring and sanctioning mechanisms." ${ }^{77}$ In some scenarios, victims and perpetrators are forced to live as neighbors because they cannot go anywhere else. ${ }^{78}$ In riot-prone cities in Gujarat, The Disturbed Areas Act, 1986, "forbids the exchange of property between Hindus and Muslims to prevent distress selling." ${ }^{\prime 79}$ Living in close proximity is not a choice for many. Dhattiwala concludes that people in conflict affected societies learn to maintain "superficial relations" with their neighbors, even when they do not trust one another. ${ }^{80}$ Even if the 1986 Disturbed Areas Act does not apply to Nellie, the compulsion of coexistence does influence the narration of harmony - the survivors cannot leave Nellie (or their homes) after the massacre.

In Nellie, the villages of the Bengali-speaking Muslims are surrounded by the Assamese Hindu and tribal villages. Many narrators would reflect that they have a single road via the Hindu villages to connect themselves to the outer world. If they were to express their grief and anger, they imagine that it would inevitably put them in a geographically vulnerable position. At the same time, the Hindu and tribal attackers also realize that they have to coexist with their Muslim neighbors, and they constantly remind themselves of the brotherhood that exists amongst them. ${ }^{81}$ The idea of coexistence reinforces the narrative of peace. Narratives of survivors, when they recollect the peaceful times and familial affinity before an event of conflict, may be speaking out from different positions, which may include fear of retaliation, being ostracized, or revoking and thereby encouraging further violence. Taking an optimistic view, one can also consider this as a holding on to the values of humanism and secularism, however idealistic they might be, inculcated during the conception of the nation by early leaders such as Nehru and Gandhi.

Two recent stories elaborate on how narratives of violence and denial of animosity are affected by spaces of coexistence. On March 27, 2018, Asansol, a town in the Indian state of West Bengal, erupted into violence over a Ram Navami procession (a Hindu festival that marks the birth of Lord Ram). ${ }^{82}$ Three people were killed. A year after the riots, a report cites the residents of Sinthla Dangal and the adjoining Ram Krishna Dangal, a Hindu-majority pocket involved in the riots, claiming that all is well after the riots of March 2018. However, the reporter senses that "there might not be any surface tension but a strong undercurrent is palpable." ${ }^{\prime 3}$ This undercurrent is hidden in the story of Sandeep Raut, who lost his mother during the riots and asserts that the Bihari (referring to the Hindus) population will not attend the public meeting of West Bengal chief minister, Mamata Banerjee, who is accused of being pro-Muslim. ${ }^{84}$

Contrary to what is seen as an "undercurrent," the riots in Asansol were in the news due to the exemplary act of a Muslim cleric, Imam Imdadul Rashidi, who lost his sixteen-year old son, Shibghatullah Rashidi, in the riots. When the riots broke out, Shibghatullah was studying in the nearby Madrassa (Muslim religious school). He rushed out for the safety of home but ended up entering the Hindu colony. Imam Rashidi was informed by the authorities near midnight that a "mutilated body of a teenaged boy" was found that could be his son. ${ }^{85}$ The Imam requested that the news not be made public, believing "if people get to know, hot-headed boys will attack the Hindus in the darkness." ${ }^{86}$ When an estimated 10,000 people gathered for the burial later that day,

\footnotetext{
${ }_{77}$ Dhattiwala, Keeping the Peace, 135.

${ }^{78}$ Ibid., 139.

${ }^{79}$ Ibid., 137; The Gujarat Prohibition of Transfer of Immovable Property and Provision for Protection of Tenants from Eviction from Premises in Disturbed Areas Act of 1991 (Gujarat Act No. 12 of 1991, April 4, 1991), (State of Gujarat, Rep. of India), accessed January 20, 2020, https://www.indiacode.nic.in/bitstream/123456789/4609/1/disturbedareasact. pdf.

${ }^{80}$ Ibid., 145.

${ }^{81}$ Villagers in Nellie and Silchang, interview with author, September 22, 2016.

${ }^{82}$ Arshad Ali, "Lok Sabha Election 2019: Riot-hit Asansol Split Between TMC, BJP," DNA, April 28, 2019, accessed May 13, 2019, https://www.dnaindia.com/india/report-lok-sabha-election-2019-riot-hit-asansol-split-between-tmc-bjp-2743835. ${ }^{83} \mathrm{Ibid}$.

${ }^{84}$ Ibid.

${ }^{85}$ Harsh Mander, "Miracles in Asansol: As Coal City Burnt in Hatred, a Muslim Cleric and Hindu Temple Healed with Love," Scroll.in, 12 April, 2018, accessed May 13, 2019, https://scroll.in/article/875325/miracles-in-asansol-as-coal-cityburnt-in-hatred-a-muslim-cleric-and-hindu-temple-healed-with-love.

${ }^{86}$ Ibid.
} 
the crowd was angry and baying for revenge. Imam Rashidi pleaded to the crowd, "if you love me then I ask from you at this moment only one promise. That with your tongue or with your hand, none of you will cause any harm to any Hindu." ${ }^{87}$ Another report quotes him saying, "if you love me then don't indulge in any violence and let peace prevail. I don't want any more lives to be lost. If you resort to any violence, then I will leave the mosque and the city." ${ }^{18}$ His address placated the crowd in such a way that Muslim boys from the neighborhood took turns guarding the few Hindu properties in the Muslim-populated area of Raniganj, where the incident happened. Imam Rashidi's plea for peace came to be heralded as heroic. He had even refused to name his son's killers. His act is said to have saved Asansol, or possibly India, from another bloodbath. ${ }^{89}$

Reports on Imam Rashidi simultaneously reminded one of a similar act of refusal to be involved in the web of violence by Yashpal Saxena, father of Ankit Saxena, a Hindu boy from Delhi, who was murdered by the relatives of his Muslim girlfriend right in front of his parents..$^{90}$ Despite political pressures from some right-wing parties to turn it into a cause for riots, Yashpal Saxena refused to blame the entire Muslim community for the crime of a few. In a few months, Yashpal Saxena went on to organize Iftar, the event when Muslims break their fast during the holy month of Ramadan, as a call for peace and brotherhood..$^{91}$

Both Rashidi and Saxena have been hailed as heroes who mitigated what could have turned into larger events of violence. Rashidi and Saxena called for peace in their cities: no other family should suffer what their families have. Saxena says that Ankit had friends from all religions, and he would frequently visit all places of worship. These were values instilled in his upbringing. Asansol, the city where Rashidi lives, has the phrase "City of Brotherhood" written over the gate that stands at its entrance. ${ }^{92}$ This narrative of harmonious dwelling and brotherhood incongruously exists amidst the incidents of violence. The idea of a secular nation still holds strong throughout these narratives despite the bitterness experienced by the various affected communities. But, what does peace mean in such settings? As both fathers call for peace in the society and requests not to politicize the deaths of their sons, can we find a difference between their emphasis on unity and forgiveness based on the communities they belong to? Are their positions different because one belongs to the minority while the other belongs to the majority? Rashidi's plea could have been based on the genuine gesture of forgiveness or on a canny calculation of fear as a minority. The insistence on peace finds a place even when they would want justice to be implemented. Both the fathers say that they would want justice for their sons' deaths while remaining unwilling to incriminate the other community. ${ }^{93}$

Amidst such mobilization toward peace, a minute crack exists in the narrative. Despite being hailed as a national hero, in an interview with Citizens for Justice and Peace (CJP), Rashidi speaks of how certain people question his citizenship. ${ }^{94}$ They accuse him of being a Bangladeshi. In response, Rashidi has to emphasize that his forefathers were freedom fighters during India's struggle for

\footnotetext{
${ }^{87}$ Ibid.

${ }^{88}$ Suvojit Bagchi and Soumya Das, "Asansol Imam's Call for Peace Comes in for Praise," The Hindu, April 2, 2018, accessed May 13, 2019, https://www.thehindu.com/news/national/asansol-imams-call-for-peace-comes-in-for-praise/ article23408750.ece.

${ }^{89}$ Sumanta Ray Chaudhuri, "Won't Name Anyone as Suspect, Says Imam Whose Son was Killed in Asansol Clashes," Hindustan Times, April 2, 2018, accessed May 13, 2019, https://www.hindustantimes.com/india-news/won-t-nameanyone-as-suspect-says-imam-whose-son-was-killed-in-asansol-clashes/story-OCxGUgVrgDLWZig9v932tJ.html.

${ }^{90}$ India Today Web Desk, “Delhi Photographer Ankit Saxena's Murder: All You Need to Know In 10 Points," India Today, February 4, 2018, accessed May 15, 2019, https://www.indiatoday.in/india/story/delhi-cm-kejriwal-condemns-ankitsaxena-s-murder-all-you-need-to-know-in-10-points-1161619-2018-02-04.

${ }^{91}$ Harsh Mander, "With his Multi-Faith Iftar in Delhi, Ankit Saxena's Father Sets an Example for These Fraught Times," Scroll.in. 7 June, 2018, accessed May 15, 2019, https://scroll.in/article/881477/with-his-multi-faith-iftar-in-delhi-ankitsaxenas-father-sets-an-example-for-these-fraught-times.

${ }^{92}$ Shiv Sahay Singh, "Communal Divide to the Fore in Asansol," The Hindu, April 27, 2017, accessed May 17, 2019, https:// www.thehindu.com/news/national/other-states/communal-divide-to-the-fore-in-asansol/article26960631.ece.

${ }^{93}$ Ibid.; Mander, With his Multi-Faith Iftar.

${ }^{94}$ Citizens for Justice and Peace (CJP), "Watch: Even After His Son was Killed, He Appealed for Peace," Imam Imdadul Rashidi interviewed by CJP, YouTube video, uploaded 11 April, 2019, 00:02:37, accessed May 14, 2019, https://www. youtube.com/watch?v=wTj1TN0 A7w.
} 
freedom, and he loves his country because it is in his blood. Saxena, on the other hand, never had to address this question of belonging, even when he challenges the Hindu-right wing heavyweights by refusing to toe their line. The Hindu-right may see him as a betrayer or a coward, but his identity and his right to belong in the nation are never questioned. The ideas of secularism are exhausted when Rashidi's act of forgiveness quickly transforms into a challenge to his citizenship. He has to invoke his ancestral identity and his lineage, as well as right to belong. Being a member of the Muslim minority, Rashidi has to be ready to defend his identity as an Indian. For a Muslim, the threat of being denounced as the outsider who does not belong is omnipresent. ${ }^{95}$

In a society torn by violence, when narrators assert the presence of harmony, their assertions may sound similar, but such declarations may arise from different origins. For a member of the Muslim minority, these statements of harmony may be based out of fear of retaliation simply by being the minority, and at other times, to claim their belonging. As Dipesh Chakrabarty said, the minority has to adapt to the ways of the majority to appear secular. ${ }^{96}$ For a member of the Hindu majority, this might not be the case. For a Muslim, it might be an attempt to not be reminded, to not remind others, or to not be ostracized as a foreign invader who lingered for too long. The perception of the Muslim as the foreign invader has become deep-rooted in places such as Gujarat. The Gujarati Hindu majority has pathologically imbibed the perception of the Muslim as the foreign invader throughout the centuries. Dhattiwala cites Gujarati linguist and author Ganesh Devy, who says, "there is only the deep, almost genetic, knowledge of Somnath and the invasions and an accumulation of prejudices." ${ }^{\prime 97}$ Thus, it becomes a given in Gujarat that Muslims are still the invaders who do not belong.

The pattern of not belonging is reiterated in the narratives from Nellie, when Riyazuddin remembers the years of the Assam Agitation..$^{98}$ The processions during this period would have slogans such as, "Mukhe daari haate paan/Chalo Miyan Pakistan" (Beard around the chin and betelleaves in hand/Miyan, let us send you to Pakistan). ${ }^{99}$ Miyan is a term of reverence in Urdu but has come to derogatorily mean the Bengali-speaking Muslims in Assam, especially those whose ancestors had migrated from the district of Mymensingh in Bangladesh. ${ }^{100}$ In the Hindu-right narrative, Pakistan is often evoked as the space where Muslims rightfully belong. ${ }^{101}$ Although the Assam Agitation was not explicitly communal, Hindu-right ideas gradually influenced it as the Rashitriya Swayam Sevak (RSS) penetrated it. The Nellie massacre is believed to be an outcome of the provocative speeches of the Hindu right, as well as extremist Muslim leaders. ${ }^{102}$ In the documentary film What the Fields Remember, ${ }^{103}$ a survivor remembers how his little daughter was killed in the massacre. A day earlier, she had joined one of the processions of the Assam Agitation with placards that said, "foreigners go away." In the heart-breaking moment when she lay dying, after the attack the next day, she asked her father, "Are we the foreigners, then?" The stoic father today remembers how the little girl did not realize who was considered the foreigner and why. ${ }^{104}$

Despite being of such political importance, the little girl's death went unaccounted for. The killings of Nellie massacre were hushed in the public memory. Of the 688 cases filed, the

\footnotetext{
${ }^{95}$ Thus, for a Muslim, the threat of being denounced as the outsider who does not belong is omnipresent.

${ }^{96}$ Chakrabarty, Remembered Villages, 2149.

${ }^{97}$ Dhattiwala, Keeping the Peace, 76; Gujarat experienced extreme Hindu-Muslim violence not during the 1947 Partition, but in the years after. In September 1990, the nation-wide campaign to construct a temple in Ayodhya in honor of Hindu god, Ram, was officiated form the city of Somnath in Gujarat. Somnath temple was a frequent target of Mahmud Ghazni during the eleventh century, which shaped the memory of the Muslim being an invader in Gujarat. See, Dhattiwala, Keeping the Peace, 13-15.

${ }^{98}$ Riyazuddin, interview with author, March 10, 2016.

${ }^{99}$ Ibid.

${ }^{100}$ This is based on my observation as a local resident of Assam.

${ }^{101}$ Pandey, Routine Violence, 132.

${ }^{102}$ Monirul Hussain, The Assam Movement: Class, Ideology and Identity (New Delhi: Manak Publications, 1993), 132.

${ }^{103}$ Subashri Krishnan, dir. What the Fields Remember (Public Service Broadcasting Trust, 2015), YouTube video, 00:51:58, uploaded March 13, 2016, accessed Aug 10, 2020, https://www.youtube.com/watch?v=599LmFwHJwU.

${ }^{104}$ Krishnan, dir., What the Fields Remember, 00:29:34-00:30:32.
} 
police submitted charge-sheets for 310 cases. ${ }^{105}$ When the Assam Accord was signed in 1985, ${ }^{106}$ the perpetrators were given total impunity, a major aspect that indicates denial. The state fails to acknowledge the wrong done. The state is perpetually nervous to permit dialogue regarding the massacre. In an interview with journalist Diganta Sharma, who wrote a very informative book on the massacre, I was told how Makiko Kimura's talk at a reputed institute in Assam was canceled thirty minutes before the scheduled time. ${ }^{107}$ Kimura reports in her book that police had asked her not to visit Nellie for research without them accompanying her. ${ }^{108}$ The state's precautions are further accentuated by facts such as that the Tiwari Commission report on the massacre was never publicly released. Commission reports on violence in India often face this fate: Jaganmohan Reddy Commission of Inquiry on the Gujarat riots of 1969, judicial inquiry by S.B. Bhansle after the Worli riots in 1974 in Mumbai, Justice Saxena Commission report on the 1980 Moradabad Riots, inquiry commission after Bhagalpur riots in 1989, Justice B.N. Srikrishna Commission report on Mumbai riots 1992-93 are a few of the reports that have not been given due attention. ${ }^{109}$ The refusal to permit discussions around such instances of violence is also a negation of the possibility to address the differences in the society and thereby a denial of the responsibility to hold the guilty accountable. Such caution is especially employed when the guilty is a majority. The refusal to attend to reports of the several commissions over the period of time has not diminished the possibility of recurring violence. Does the state really deny the existence of fault-lines, or is it the bias inherent in the state controlled by the majority? Such silences by the state influence the narrators' position and ability to speak in the aftermath of violence; the minority becomes conscious of possible retaliation, while the Hindu majority, though, can be sensitive toward the conflict situation, can also bask in a statepropagated idea of immunity.

The confidence provided by having a state-supported appearance of having immunity, especially when a person belongs to the majority, was evident during the anti-Sikh riots of 1984 . On October 31, 1984, when the prime minister of India, Indira Gandhi, was assassinated by two Sikh security guards, a three-day pogrom ensued. Sikhs were hunted down throughout Delhi in a series of planned attacks, mostly by Hindu mobs, supervised by Congress (I), ${ }^{110}$ the political party in power. ${ }^{111}$ It was primarily neighbors and other locals involved in the attack, but the survivors feared further attacks if they pointed them out. The survivors, however, did not hesitate to "freely and unjustifiably" blame the Dalits and Muslims. ${ }^{112}$ That the survivors were scared of implicating the Hindu perpetrators seem understandable, given that the latter had a certain protection from the state. The threat of having to share space as neighbors in the future also triggered the fear. In contrast, incriminating the Muslims and the Dalits, who had no participation in the attack, is noteworthy. As marginalized communities, the Muslims and the Dalits were vulnerable and definitely had no state protection. Implicating them seemed to be the next possible thing to attaining justice by the Sikhs, who were considered a part of the Hindu majority before the anti-Sikh riots. The fear of the majority Hindu in power and in the neighborhoods, along with the callousness toward the minorities influenced the survivor narratives. Thus, narratives of survivors and perpetrators emerge from different places of securities and insecurities, which leads to the determination on whether these narratives will reflect the discord or the patterns of harmony and brotherhood.

\footnotetext{
${ }^{105}$ Kimura, The Nellie Massacre of 1983, 74.

${ }^{106}$ Problem of Foreigners in Assam, Memorandum of Settlement (August 15, 1985), (State of Assam, Rep. of India), accessed August 19, 2020, https://assamaccord.assam.gov.in/sites/default/files/swf utility folder/departments/ assamaccord medhassu in oid 3/portlet/level 1/files/The\%20Assam\%20Accord\%20-\%20English.pdf.

${ }^{107}$ Diganta Sharma, interview with author, March 11, 2016.

${ }^{108}$ Kimura, The Nellie Massacre of 1983, 133.

109 “1984 is a Symptom of a Bigger Disease," Livemint, August 27, 2018, accessed January 20, 2019, https://www.livemint. com/Opinion/Ejr322Pwxl1qOPs7bTayZO/1984-is-a-symptom- of-a-bigger-disease.html.

${ }^{110}$ The political party Congress split in 1978 to form two fractions, Congress (O), 'O' signifying old, and Congress (I), 'I' stands for Indira (Gandhi).

${ }^{111}$ Anshu Saluja, "Reading '84 Through the Lens of Oral History," in Proceedings of the Indian History Congress 75 (2014), 1362-1369, accessed January 23, 2020, https://www.jstor.org/stable/44158530.

${ }^{112} \mathrm{Ibid}$; Dalits are constitutionally considered to within the Scheduled caste.
} 
The insecurity that accompanies being the vulnerable and lesser minority and belonging to the community perceived as the foreigner who needs to be ousted shaped the narratives of the survivors of the Nellie massacre. This fear is renewed and further affirmed during the updating of the National Register of Citizens (NRC) in Assam. NRC was prepared for the first time under a directive of the Ministry of Home Affairs during the Census of 1951. The census documents containing information on the relevant particulars of every person enumerated were copied in registers. In 2013, the process of updating the NRC had begun in Assam. Citizens had to prove their family-tree and their connection to a legacy data, a number that had been given during the NRC of 1951. The first draft of the updated NRC was released on December 31, 2017 and the complete draft on July 3, 2018. The complete draft left out nearly four million people, creating a potential pool of the world's largest stateless population. The final draft released on August 31, 2019 finally left out almost 1.9 million applicants. ${ }^{113}$

The threat of religion-based citizenship in India goes against the very foundational ideas of secularism that Nehru had envisioned, "a non-identitarian 'Indian-ness' which would bear (only) the marks of modern citizenship," as embedded in the Constitution of India. ${ }^{114}$ The Citizenship Amendment Act, 2020 (CAA) became a major instrument in asserting "the homogenous Hindu identity and culture as coterminous with the nation, India." ${ }^{\prime 15}$ CAA indicates that India has entered an early stage of genocide. ${ }^{116}$ Genocide Watch marks India as having reached stage five of genocide, i.e., organization, when the state uses militias, formal or informal, to provide deniability of state responsibility, organizes police to spy, arrest, torture, and murder people suspected of opposing the dominant leaders, and motivating to target the religious majority, namely the Hindus, through mass media. ${ }^{117}$ Due to the CAA along with the NRC, India is simultaneously undergoing several stages of genocide - classification: distinguishing people by religion; symbolization: distinguishing the target group by dress and appearance; and discrimination: a dominant group using laws to deny rights to other groups. ${ }^{118}$ The NRC becomes the instrument of classification of "the alien" by their religion and descent, and together with the CAA of 2019, it has the potential to become an instrument of discrimination by taking away citizenship rights. Along with classification and discrimination, symbolization and polarization can also be seen as conspicuously present in today's India.

When I began my field visits in Nellie in early 2016, the process of applying to be included in the NRC had just begun. Many individuals, even those who were well-educated, were struggling to understand the different clauses and requirements of the application process. In Nellie, most of the people are not very literate. There were bound to be confused about the application process and the paperwork involved, anomalies were thus inevitable. In the interviews during the early phase of my research, there were scattered references to the process and how it has made them fearful of being underlined as the foreigner, even if they have all the proper documents. For them, the process of applying to be included in the NRC list was a repetition of the rigorous process of which they had to endure in order to prove their citizenship when they were declared a doubtful voter (D-Voter)-individuals who were classified as D-voters would be discredited as citizens and have their voting rights challenged. Nevertheless, they also welcomed the decision to update the database of citizens, since doing so would prove that they were not foreigners but rather rightful citizens. In subsequent years as I visited them, the community became more careful in discussing the massacre and the documents they might or might not have. While traveling in public auto-

\footnotetext{
${ }^{113}$ Home and Political Department, White Paper on Foreigner's Issue, Government of Assam, 2015, accessed January 20, 2019, http://onlineedistrict.amtron.in/web/home-and-political-department/white-paper.

${ }^{114}$ Sunder Rajan and Needham, Introduction, 7; The Constitution of India, (January 26, 1950), (Rep. of India), accessed August 19, 2020, https://www.india.gov.in/sites/upload files/npi/files/coi part full.pdf.

115 Tejani, Indian Secularism, 88; Citizenship (Amendment) Act of 2019, (Act No. 47 of 2019, December 12, 2019), (Republic of India), accessed December 16, 2020, http://egazette.nic.in/WriteReadData/2019/214646.pdf

${ }^{116}$ CAA of 2019.

117 “Ten Stages of Genocide Interactive World Map," Genocide Watch, accessed January 1, 2020, https://www. genocidewatch.com/ten-stages-of-genocide-world-map; Stanton, The Ten Stages of Genocide.

${ }^{118}$ Stanton, The Ten Stages of Genocide.
} 
rickshaws crowded with other passengers, I would overhear how someone's daughter had to rush to her parental home in Nellie for verification of documents, and other similar instances. Toward the end of my research period by 2019, people were cautious with their responses during interviews; they were suspicious, and they vocalized their suspicion, too. The interviewees in later stages were dismissive of the question of whether all was or has been well.

The missing names in the NRC list becomes a threat to the Muslim community when seen together with the CAA of 2019, which has provisions to bestow citizenship upon people of six communities, namely Hindus, Sikhs, Parsis, Christians, Jains and Buddhists, from Pakistan, Bangladesh and Afghanistan. ${ }^{119}$ If we read the NRC together with the provisions of the CAA, it becomes logically comprehensible that the Hindu-Bengali community may or may not make a large share of those left out of the NRC list, but if they indeed are left out, they might be able to reapply for citizenship, even without any documents. Similarly, it can be understood that the Bengali-speaking Muslims, left out of the NRC can be deprived of their citizenship, if the NRC and CAA are read together. The Bengali-speaking Muslim community has become more wary of being at the receiving end yet again. Over the years, the Nellie massacre had become a metonymy for all the injustices meted out to them. Although the media has repeatedly evoked the massacre as a significant political moment for the community, the community remained tight-lipped. A gradual polarization in the discourse has emerged over the years. For instance, individual artists have made music videos replete with hate-inducing images and songs that threaten foreigners with dire consequences. Although a song occasionally evokes the concept of "Hindu-Muslim Bhai Bhai," i.e., Hindus and Muslims are brothers, it simultaneously falls back on the image of the Bengali-speaking Muslim as the infiltrator who needs to be killed and not merely chased away or deported. ${ }^{120}$ In the backdrop of such changing political and social dynamics, the narrative in Nellie becomes even more cautious - a society once seared by such large-scale violence cannot be immune to the prospect of its repetition.

\section{Conclusion}

The various narratives of survivors and perpetrators of various violent events in India prove that violence afflicted societies are situated on a fragile balance. This fragility is revealed in the caution the narrators exercise in their narratives, whether they be narratives from the Partition, the Gujarat Pogrom, or the Nellie Massacre. The narratives from these events can be seen as representative of the numerous other events of violence and the societies and communities that evolve after the occurrence of such events. These narratives emerge from various positions of the narrators. When a narrator acknowledges the fault-lines that exist or might have existed before the event to the interviewer, most often an outsider, the narrators express an understanding that recognizing the differences is an important step towards preventing similar occurrences of violence in the future. In contrast, when the narrators try to hold on to narratives of harmony from the past- often grasping on to the image of a family and presenting the events as normal family skirmishes- they may be trying to assuage violence in the present or prevent violence in the future. Besides the fact that it may be a willful overlooking of the reality, such narratives of harmony can also emerge from various political and social locations of the narrators

On the one hand, assuming that both communities are sincere in their assertion of a harmonious past in their narration is judicious, their claim to brotherhood may indeed be true. However, the narrator, belonging to the politically dominant majority, also speaks from a position of security. Although they might fear that the opposing communities may attack them, they are mostly secure in the knowledge that they are the numerically stronger community. They may be aware of the restrictions of geography in a mixed society, but they know they will have more power to retaliate in case of any unforeseen incident.

On the other hand, the minority community does not have numbers in their favor, which they know. Their narratives of harmony may originate from a point of fear of numbers. Similar to the

\footnotetext{
${ }^{119}$ CAA of 2019.

${ }^{120}$ Suraj Gogoi and Abhinav Borbora, “In the Guise of Protest Music, Assamese Artists Churn Out Hate Speech," The Wire, May 9, 2019, accessed May 15, 2019, https://thewire.in/the-arts/assam-protest-music-citizenship-bill-hate-speech.
} 
majority, they are sensitive to the realities and vulnerabilities of coexisting and the challenges that could stem from communal conflict. As the minority, the Muslims in India, and particularly the Bengali-speaking Muslims in Assam, have to constantly encounter challenges with regards to their identity, their right as citizens, and the slur of being foreigners. Many times, conflicts arise out of this challenge itself. When the narrators speak in a post-conflict society, they are mindful of these environments in which they stand. Although the positions from which they speak may justify their narratives, not addressing the reality of the fragility and the existing differences will only further deepen the divide.

\section{Acknowledgements}

I would like to thank my PhD supervisor Dr. Paulomi Chakraborty for her feedback on the article and the Indian Institute of Technology Bombay for funding my attendance in the conference "Denial: The Final Stage of Genocide" at University of North Carolina at Charlotte, where parts of this paper were first selected and presented.

\section{Bibliography}

Agence France-Presse (AFP), "Assam NRC: Over Four Million People Left Off-Draft Since Enforcement of Exercise, Muslims Majority Among Those Who 'Fear for Future,"' Firstpost, July 14, 2019. Accessed July 15, 2019. https://www.firstpost.com/india/assam-nrcover-four-million-people-left-off-draft-since-enforcement-of-exercise-muslims-majorityamong-those-who-fear-for-future-6989831.html.

Ali, Arshad. "Lok Sabha Election 2019: Riot-hit Asansol Split Between TMC, BJP." DNA, April 28, 2019. Accessed May 13, 2019. https://www.dnaindia.com/india/report-lok-sabha-election2019-riot-hit-asansol-split-between-tmc-bjp-2743835.

Bagchi, Suvojit and Soumya Das. "Asansol Imam's Call for Peace Comes in for Praise." The Hindu, April 2, 2018. Accessed May 13, 2019. https://www.thehindu.com/news/national/asansolimams-call-for-peace-comes-in-for-praise/article23408750.ece.

Brass, Paul R. "The Partition of India and Retributive Genocide in the Punjab 1946-47: Means, Methods, and Purposes." Journal of Genocide Research 5, no.1 (2003), 71-101. Accessed December 20, 2019. Doi: 10.1080/14623520305657

Butalia, Urvashi. The Other Side of Silence: Voices from the Partition of India. New Delhi: Penguin Books, 1998.

Campbell, Bradley. "Contradictory Behaviour During Genocides." Sociological Forum 25, no.2 (2010), 296-314. Accessed December 22, 2019. https://www.jstor.org/stable/pdf/40783395. pdf.

Chakrabarty, Dipesh. "Remembered Villages: Representations of Hindu-Bengali Memories in the Aftermath of the Partition." Economic and Political Weekly 31, no. 32 (1996), 2143-2145, 21472151. Accessed October 4, 2018. https://www.jstor.org/stable/4404497.

Chaudhuri, Sumanta Ray. "Won't Name Anyone as Suspect, Says Imam Whose Son was Killed in Asansol Clashes." Hindustan Times, April 2, 2018. Accessed May 13, 2019. https://www. hindustantimes.com/india-news/won-t-name-anyone-as-suspect-says-imam-whose-sonwas-killed-in-asansol-clashes/story-OCxGUgVrgDLWZig9v932t].html.

Citizens for Justice and Peace (CJP). "Watch: Even After His Son was Killed, He Appealed for Peace." Imam Imdadul Rashidi interviewed by CJP. YouTube video. Uploaded April 11, 2019, 00:03:44. Accessed May 14, 2019. https://www.youtube.com/watch?v=wTj1TN0 A7w.

Citizenship (Amendment) Act of 2019 (Act No. 47 of 2019, December 12, 2019), (Rep. of India). Accessed December 16, 2020. http://egazette.nic.in/WriteReadData/2019/214646.pdf.

Citizenship (Amendment) Bill of 2016 (Bill No. 172 of 2016, July 15, 2016), (Rep. of India). Accessed January 20, 2020. https://www.prsindia.org/sites/default/files/bill files/Citizenship (A) bill, 2016 0.pdf.

Constitution of India (January 26, 1950). (Rep. of India). Accessed August 19, 2020. https://www. india.gov.in/sites/upload files/npi/files/coi part full.pdf. 
Dhattiwala, Raheel. Keeping the Peace: Spatial Differences in Hindu-Muslim Violence in Gujarat in 2002. New York: Cambridge University Press, 2019. Doi: $10.1017 / 9781108596312$

Genocide Watch, "Ten Stages of Genocide Interactive World Map." Accessed January 1, 2020. https://www.genocidewatch.com/ten-stages-of-genocide-world-map.

Gogoi, Suraj and Abhinav Borbora, "In the Guise of Protest Music, Assamese Artists Churn Out Hate Speech," The Wire, May 9, 2019. Accessed May 15, 2019. https://thewire.in/the-arts/ assam-protest-music-citizenship-bill-hate-speech.

Gujarat Prohibition of Transfer of Immovable Property and Provision for Protection of Tenants from Eviction from Premises in Disturbed Areas Act of 1991 (Gujarat Act No. 12 of 1991, April 4, 1991), (State of Gujarat, Rep. of India). Accessed January 20, 2020. https://www. indiacode.nic.in/bitstream/123456789/4609/1/disturbedareasact.pdf.

Home and Political Department. White Paper on Foreigner's Issue. Government of Assam, 2015. Accessed January 20, 2019. http://onlineedistrict.amtron.in/web/home-and-politicaldepartment/white-paper.

Hussain, Monirul. The Assam Movement: Class, Ideology and Identity. New Delhi: Manak Publications, 1993.

India Today Web Desk, “Delhi Photographer Ankit Saxena's Murder: All You Need to Know In 10 Points." India Today, February 4, 2018. Accessed May 15, 2019. https://www.indiatoday.in/ india/story/delhi-cm-kejriwal-condemns-ankit-saxena-s-murder-all-you-need-to-knowin-10-points-1161619-2018-02-04.

Kannabiran, Kalpana. "Introduction: The Habitations of Violence in India." In Violence Studies, edited by Kalpana Kannabiran, 1-57. New Delhi: Oxford University Press, 2016.

Khanna, Satti and Peter Chappell, dirs. A Division of Hearts. New York: Icarus Films, 1987. 57 minutes.

Krishnan, Subashri, dir. What the Fields Remember. Public Service Broadcasting Trust, 2015. YouTube video, 00:51:58. Uploaded March 13, 2016. Accessed Aug 10, 2020. https://www.youtube. com/watch?v=599LmFwHJwU.

Kimura, Makiko. The Nellie Massacre of 1983: Agency of Rioters. New Delhi: Sage Publications, 2015.

Livemint. "1984 is a Symptom of a Bigger Disease," August 27, 2018. Accessed January 20, 2019. https://www.livemint.com/Opinion/Ejr322Pwxl1qOPs7bTayZO/1984-is-a-symptom-of-abigger-disease.html.

Mander, Harsh. "Miracles in Asansol: As Coal City Burnt in Hatred, a Muslim Cleric and Hindu temple Healed with Love." Scroll.in, April 12, 2018, Accessed May 13, 2019. https://scroll. in/article/875325/miracles-in-asansol-as-coal-city-burnt-in-hatred-a-muslim-cleric-andhindu-temple-healed-with-love.

."With his Multi-Faith Iftar in Delhi, Ankit Saxena's Father Sets an Example for these Fraught Times," Scroll.in, June 7, 2018. Accessed May 15, 2019. https://scroll.in/article/881477/withhis-multi-faith-iftar-in-delhi-ankit-saxenas-father-sets-an-example-for-these-fraughttimes.

Menon, Ritu and Kamala Bhasin. Borders and Boundaries: Women in India's Partition. New Brunswick: Rutgers University Press, 1998.

Miller, Leslie J. "Violent Families and the Rhetoric of Harmony." The British Journal of Sociology 41, no. 2, (1990), 263-288. Accessed May 6, 2019. https://www.jstor.org/stable/590873.

Pandey, Gyanendra. Remembering Partition: Violence, Nationalism and History in India (Contemporary South Asia). Cambridge: Cambridge University Press, 2001. Doi: 10.1017/CBO9780511613173

--------. Routine Violence: Nations, Fragments, History. California: Stanford University Press, 2006.

Problem of Foreigners in Assam, Memorandum of Settlement (August 15, 1985), (State of Assam, Rep. of India). Accessed August 19, 2020, https://assamaccord.assam.gov.in/sites/default/files/ swf utility folder/departments/assamaccord medhassu in oid 3/portlet/level 1/files/ The \%20Assam\%20Accord\%20-\%20English.pdf.

Saikia, Yasmin. Women, War and the Making of Bangladesh: Remembering 1971. New Delhi: Women Unlimited. 2011. Doi: $10.1215 / 9780822394280$ 
Saluja, Anshu. "Reading '84 Through the Lens of Oral History." In Proceedings of the Indian History Congress 75 (2014), 1362-1369. Accessed January 23, 2020. https://www.jstor.org/ stable/44158530.

Sampath, G. "Are Fears over the Citizenship (Amendment) Act Misplaced?" The Hindu, December 19, 2019. Accessed December 20, 2019. https://www.thehindu.com/opinion/op-ed/arefears-over-the-citizenship-amendment-act-misplaced/article30341818.ece.

Sharma, Diganta. Nellie, 1983. Jorhat: Ekalabya Prakashan, 2007.

Singh, Shiv Sahay. "Communal Divide to the Fore in Asansol," The Hindu, April 27, 2017. Accessed May 17, 2019. https://www.thehindu.com/news/national/other-states/communal-divideto-the-fore-in-asansol/article26960631.ece.

Slater, Joanna and Nisah Masih. „India's 2019 Elections: What you need to know.“ The Washington Post, May 22, 2019. Accessed January 30, 2020. https://www.washingtonpost.com/ world/2019/03/11/indias-elections-what-you-need-know/.

Stanton, Gregory H. “The Ten Stages of Genocide." Genocide Watch, 2016. Accessed January 1, 2020. http://genocidewatch.net/genocide-2/8-stages-of-genocide/.

Sunder Rajan, Rajeswari and Anuradha Dingwaney Needham. "Introduction." In The Crisis of Secularism in India, edited by Anuradha Dingwaney Needham and Rajeswari Sunder Rajan, 1-42, Ranikhet: Permanent Black, 2009.

Tejani, Shabnum, Indian Secularism: A Social and Intellectual History 1890-1950. Ranikhet: Permanent Black, 2007. 